\title{
The Enabling Environment for Participation in Water and Sanitation: A Conceptual Framework
}

\author{
Alejandro Jiménez ${ }^{1, *} \mathbb{C}^{\mathbb{D}}$, Hélène LeDeunff ${ }^{2}$, Ricard Giné ${ }^{1}{ }^{\circledR}$, Johanna Sjödin ${ }^{1}$, Ryan Cronk ${ }^{3}{ }^{(}$, \\ Sofia Murad ${ }^{4}$, Marina Takane ${ }^{4}$ and Jamie Bartram ${ }^{3}$ (D) \\ 1 Stockholm International Water Institute, 10055 Stockholm, Sweden; ricard.gine@siwi.org (R.G.); \\ johannasjodin@outlook.com (J.S.) \\ 2 Faculty of Arts and Social Sciences, University of Sydney, Sydney 2006 NSW, Australia; \\ helene.ledeunff@sydney.edu.au \\ 3 The Water Institute, Department of Environmental Sciences and Engineering, Gillings School of Global \\ Public Health, University of North Carolina at Chapel Hill, Chapel Hill, NC 27599, USA; \\ rcronk@live.unc.edu (R.C.); jbartram@email.unc.edu (J.B.) \\ 4 Department of Public Health, Environmental and Social Determinants of Health (PHE), World Health \\ Organization, 1211 Geneva, Switzerland; sofia.jj.murad@gmail.com (S.M.); takanem@who.int (M.T.) \\ * Correspondence: alejandro.jimenez@siwi.org; Tel.: +46-8-121-360-41
}

Received: 11 January 2019; Accepted: 5 February 2019; Published: 12 February 2019

\begin{abstract}
Participatory approaches are an important component of institutional frameworks for the governance of water resources and services. Studies on public participation in water management provide evidence for the outcomes of public participation and insights into the types of methods and the contexts under which participation can be meaningful. However, participatory processes are complex, and there is no single method by which to interpret, approach and implement them. This paper explores elements from the theory and practice of participation, applied to the management of water resources and water and sanitation services. Based on an in-depth literature review, we analyze the forms of participation in water and sanitation, their outcomes, as well as the contextual factors and procedural elements of participatory processes that affect their success. Contextual factors are those that are largely outside of the control of agencies or participants (e.g., demographics, history, and culture) or those that can only be influenced by management and institutional decisions in the mid- and long-term (e.g., the legal and institutional framework); while procedural elements are those over which agencies and participants have considerable control when designing and executing participatory efforts (e.g., representativeness and inclusivity, access to information, and opportunity to influence). We propose a framework that interrelates and integrates both contextual factors and procedural elements of participation. It, includes three additional aspects that are influenced by, and in turn influence, the context and the process: existing capacities for implementation of meaningful participatory processes, the resources that are allocated to them, and attitudes towards participatory processes. The framework helps conceptualize what we call the enabling environment for active, free, and meaningful participation in the delivery of water and sanitation services. By breaking down the complexities of participation, the framework supports practitioners and decision-makers to better design and implement participatory processes in water resources and water and sanitation services.
\end{abstract}

Keywords: participation; enabling environment; contextual factors; procedural elements; water and sanitation

\section{Introduction}

Participation has many definitions and can be referenced through multiple concepts, such as 'engagement', 'empowerment', 'involvement', 'consultation', 'deliberation', 'dialogue', 'partnership', 
'outreach', 'mediation', 'consensus building', and 'civic science' [1]. Enserink and colleagues [2] define participation as "the involvement of individuals and groups-i.e., the public or stakeholders-that are positively or negatively affected by or are interested in a proposed intervention". Regardless of definition, the central concept is to give people a meaningful role in decisions-typically from the government- that affect them [3]. The term "participatory processes" can be used to refer to processes that actively involve not only managers and government officials, but also other interested parties such as citizens, the private sector, or civil society organizations [4]. In development, including water and sanitation, participation has been widely advocated since the 1980's, largely inspired by Paulo Freire's Participatory Action Research [5] and Robert Chambers work on "putting the last first" [6]. In essence, with the stated objective "to give the poor a part in initiatives designed for their benefit" [7], in hope of enhanced sustainability. However, unless certain conditions are in place, participation will not produce sustainable outcomes.

This paper (i) reviews the evidence on participation in water and sanitation, and (ii) suggests a pragmatic conceptual framework that identifies what influences the outputs, outcomes, and impacts of participatory processes.

The participation of parties affected by or interested in an issue has been recognized as a human right: "active, free, and meaningful" participation is a right defined in Article 2 (3) of the United Nations Declaration on the Right to Development [8]. The former Special Rapporteur on the Human Right to Water and Sanitation who dedicated her 2014 report to the requirements of the right to participation and the elements needed for the right to be realized [9]. The report acknowledges the challenges of participatory processes, arguing that when they do not address entrenched power structures and marginalization, they risk reinforcing and "legitimizing" inequalities; but where they are free, meaningful and inclusive, the improvements in sustainability and empowerment are significant.

Several international agreements have underlined the importance of participation, from the 1992 Rio Conference to directives and statements on management of water resources and drinking water and sanitation services. The 1992 Dublin Statement on Water and Sustainable Development, Agenda 21 [10], the 1998 Convention on Access to Information, Public Participation in Decision-making and Access to Justice in Environmental Matters (Aarhus Convention) [11], the EU Water Framework Directive [12], and the 2001 Bonn Recommendations for Action [13], state that policies regarding water must be developed on the basis of consultations with those affected. Particularly important is the principle of Free Prior and Informed Consent (FPIC) to projects. This entails affected populations being free from coercion or manipulation, involved in decision making before plans are made, having the technical and legal knowledge required to make decisions, and ultimately reserving the right to withhold consent.

The 2030 Agenda for Sustainable Development [14] was a milestone in establishing participatory approaches as a necessary feature of decision-making in development. It is an ambitious "plan of action for people, planet, and prosperity" comprised of 17 Sustainable Development Goals (SDGs). The SDGs represent a considerable increase in scope and ambition over the Millennium Development Goals. They contain both 'Outcome' targets (i.e., circumstances to be attained) and 'Means of Implementation' (MoI) targets, which address the enabling environment and resources needed to achieve the 'outcome' targets. The 2030 Agenda includes a standalone goal on water and sanitation (Goal 6), which aims to "ensure availability and sustainable management of water and sanitation for all". Participation is singled out as one of the two MoI important to reaching this ambitious target. Target $6 . \mathrm{b}$ is to "Support and strengthen the participation of local communities in improving water and sanitation management". Supporting and strengthening stakeholder participation are framed as both ends and means. Participation is essential to the sustainability of water and sanitation management options [15], and is also as a means for development, in line with the human rights perspective. Target $6 . \mathrm{b}$ is the only SDG target to mention public participation as a Means of Implementation in the management of resources or services [16]. 
Despite the significant efforts dedicated to setting targets, milestones and goals, there is little consensus on what participation means in practical terms. Indeed, different rationales are put forth to motivate the adoption of public participation initiatives [17]. From an ethical point of view, participation is advocated as "the right thing to do". There is also a legal rationale for participation [18], since participatory approaches are acknowledged in policies, international declarations, and conventions. Since participation is recognized as a human right, normative motives underpin the claim that individuals must be able to influence decisions that affect their own lives, and that States have to guarantee that decision-making processes are inclusive and do not entrench inequalities [19]. Others advocate for participation as a means leading to better ends [20]. Instrumental rationales contend that public engagement is the most appropriate way to increase public trust or to reduce conflicts in decision-making processes. Participation can also be presented as an end in itself [21-24].

The Aarhus Convention lists four practical benefits of public participation. The first is that processes of public engagement enhance the quality and implementation of decisions, acknowledging that communities often have special knowledge of local conditions, in addition to the practical implications and limitations of proposed activities. Second, the implementation of decisions benefits from the inclusion in the process of all those interested in and affected by the issue. Third, participation increases public awareness. Fourth, opportunities for the public to express their concerns and having them addressed are empowering and increase confidence in society generally.

Active, free, and meaningful participation is an ambitious goal, and the conditions necessary to realize its benefits are not always in place. One critique is that evidence on the benefits of participation is inconclusive, e.g., $[1,4,24]$. Methodologies are also an issue. When participatory processes are not properly designed or implemented, they can have adverse consequences. Failing engagement can result in stakeholder fatigue, unmet objectives, and legitimization of marginalization and inequalities [25-30]. Other authors argue that participation be disempowering. When manipulated by powerful interests, participatory processes can exclude or function as a smokescreen behind which decision-making institutions conduct business as usual, e.g., [30]. Too often "participation" is an obligatory component of water projects put in place to secure their legitimacy. Such projects often disregard the fact that communities are not homogenous, and the benefits of participation risk being captured by a local elite [31]. Furthermore, in some cases, the reasons for failing services have to be addressed at higher levels of governance. It is in response to these tensions that we propose to clarify the concept and the approaches of participatory practices.

This review paper synthesizes evidence on participation in water and sanitation. The two aims of the study are: (1) to identify how participation outcomes are realized in water and sanitation, and (2) to provide a framework to support the design and implementation of participatory processes. To explore the first aspect-the impacts of participation in the provision of water and sanitationwe gathered learnings from theory and documented experience. We were particularly interested in how participation was defined in those studies, and what elements contributed to beneficial effects and successful participatory processes. To develop a practical tool for understanding at what level(s) participation could be the most effective, we build on the main findings from the review to develop a conceptual and practical framework. This integrates the key attributes that enable meaningful participation. The framework offers a contextual model for understanding the complexities of participation. In doing so, it serves as a guide for practitioners and decision-makers to promote the sound implementation of participatory approaches in water resources and services.

\section{Methods}

The paper is based on a literature review. The review first defined the guiding questions for the review; the next step was to identify and select relevant articles and reports; subsequently, selected manuscripts were reviewed and the results collated, summarized, and reported; a consultation enabled the co-authors to contribute to the analysis. The review sought to identify good participatory practices 
and challenges faced by practitioners when delivering participatory approaches and did not assess the quality of studies.

Two questions guided the review: (1) How are participatory processes designed and implemented? And (2) what are the results achieved through these processes? To address these questions, the review focused on four aspects of participation: the context, the process, the outcomes, and the impacts. The review considered scholarship from the fields of water governance, water management, and community-based services. Although some scholars distinguish between participation and community management, e.g., [32,33], the use of the term "participation" in this review comprised both community-driven efforts for the management of water resources and supply of water and sanitation services, as well as the decentralization of decision-making to the local level.

Literature search strategy included peer-reviewed publications published during the period 1990-2016. Four online academic literature databases were reviewed: Scopus, University of New South Wales Library, Environment Complete-EBSCO, Business Source Premier-EBSCO Engineering Village 2 and ProQuest. These index the most popular journals. Subsequently, references from relevant articles were scanned to identify further papers. This snowball technique was adopted to ensure a comprehensive and thorough search. In addition to peer-reviewed articles, international agreements and declarations related to "participation", reports produced by UN bodies, and other grey literature were assessed.

Search queries consisted of combinations of keywords around three key areas: (1) participation in water resources management, (2) participation in water supply management, and (3) participation in sanitation management (see Table 1). One additional research area-the evaluation and measurement of participation in general-was covered by a number of review articles and theoretical literature, selected non-systematically.

Table 1. Keywords and syntax used for literature search.

\begin{tabular}{c} 
\#1 Participation in water resources management \\
\hline Participat* AND “Water resources” AND (measure OR evidence OR benefits OR management OR \\
governance OR policies OR engagement OR community) \\
\#2 Participation in water supply management \\
Participat* AND (“Water supply" OR “Water services) AND (measure OR evaluat* OR engagement OR \\
community OR citizen OR inclusive OR self-help OR collab* OR cooperat* OR impact OR benefit OR lesson \\
OR evidence OR improve* OR assessment OR outcome) \\
\#3 Participation in sanitation management \\
Participat* AND Sanitation AND (measure OR evaluat* OR engagement OR community OR citizen OR \\
inclusive OR self-help OR collab* OR cooperat* OR impact OR benefit OR lesson OR evidence OR improve* \\
OR assessment OR outcome) \\
\#4 \#1 OR \#2 OR \#3
\end{tabular}

Note: The symbol * refers to the set of all words from the same root that can be created by different endings.

Articles eligible for inclusion in the study were review articles, theoretical and empirical papers with no geographical limits, if they addressed one of the four research areas: (1) the measure of participation in general, (2) the measure of participation in water resource management, (3) the measure of participation in water supply services, and (4) the measure of participation in sanitation. The first search area provided a background on theoretical approaches and trends in evaluating participation. Articles in the second category provided information about initiatives conducted in a related field but were not systematically exploited. Papers in the third and fourth search areas were classified as (1) "urban" and (2) "rural". In all four areas, and regardless of the design and structure of the process, the evaluation of participation could relate to any type of change defined as an outcomes or outputs of participation, whether "material, social, behavioral, or institutional learning and change" [1]. 
A broad range of search terms were needed to identify articles relevant to a wide range of participatory practices. As a result, the initial database search returned a large number of potential papers for analysis. Exclusion criteria were: irrelevant subject areas, language, and document types. Records were exported to EndNote version X7. Duplicates were removed manually after assembling citations.

Abstracts and titles were screened against the inclusion and exclusion criteria. Selected documents were downloaded. The eligibility of selected documents was determined through full text assessment. Only papers that explicitly addressed outcomes or outputs of participatory processes were kept in the corpus, which resulted in 67 scientific documents for in depth study. The study framework guided the organization of extracted data.

\section{Participation in Water and Sanitation: The Outcomes and Impacts}

Reed suggests that stakeholder participation for environmental management was introduced in the 1960s [34]. Since then, considerable resources have been invested in participatory approaches and research studies have been conducted to evaluate these practices. Some researchers have focused on the quality of the participation process [35], while others have gathered evidence on the effects of participation, such as the influence on policy making, e.g., [35,36], or on policy effectiveness for resources management or on service delivery outcomes, e.g., [37,38]. Similarly, scholars have developed different conceptual and evaluation frameworks for participatory processes. This stream of work has given special attention to the process [20,39-42], the outcomes, or the impacts [43-46] or to a combination of processes, outcomes and impacts [47-51].

One illustrative framework for understanding outcomes and impacts of participatory approaches was developed by Hassenforder et al. [52], who define (i) outputs as the immediate products of the participatory process, (ii) outcomes as the "effects of the process on the behavior of key actors in the system", and (iii) impacts as the extent to which participatory processes address the concerns that led to their implementation. Typical outputs include reports, assessments, and policy recommendations. Outcomes refer to improvements in social capital, individual/institutional learning, reflexivity, and behavior change [53]. Impacts include benefits in terms of efficiency and effectiveness of the process, individual and household benefits [54], and policy or developmental outcomes [22], such as improvement of the overall environmental situation. Drawing on these definitions, we identify five types of potential outcomes and impacts of participation in water and sanitation services delivery:

(a) Legitimacy of the process: Participation in collective decision-making processes is a source of legitimacy for policy and program process. In turn, legitimacy improves the acceptance of process outcomes. With strengthened legitimacy, the responsiveness of decision makers to affected parties is improved. Thereby, participatory approaches help to take stakeholder values into account and contribute to building trust $[29,55]$.

(b) Increased awareness from the population on water related issues: The Aarhus Convention specifically mentions the enhanced awareness on environmental issues as one of the benefits of participatory processes. This is also suggested by several case studies, e.g., [56].

(c) Participant empowerment: The participation of stakeholders in the decisions that affect them increases their capacity to influence such decisions, and thus increases their ownership of, commitment to and confidence in the outcomes [57-60].

(d) Better management and accountability: Participation and citizen engagement have been primarily defined as sources of empowerment and conditions for accountability [61-63]. Participation improves management decisions, as it allows for the integration of different sources of knowledge and increases the capacity for selecting suitable solutions [64]. Several qualitative studies suggest that participation strengthens participants' agency or social capital [65], trust and connectivity [66], shared knowledge [67], capacity [59], and social learning [57]. These are relational capabilities and features of self-development [68] that are assumed to result from participation and increase participants' ability to act collectively and ultimately better manage 
water sources. They contribute to the disruption of traditional power relations by including a variety of viewpoints, including those of the most vulnerable, and by increasing participants' influence on decisions. The adoption of more interactive types of governance is also justified by increasing scientific uncertainty [1], disputes [69], and antagonistic situations [70] in the water sector. In this regard, participation arguably contributes to reducing conflicts and increasing people's commitment to the outcomes of processes.

(e) Improved sustainability: As a result of the above, the effective involvement of users translates into more effective and sustainable management of services and resources [60,71,72]. In some contexts, the failure of the "command and control" model to govern complex systems such as natural resources [73] and to provide services, e.g., [71,74,75], has played a crucial part in justifying the shift toward more public participation in water services management. Better inclusion of the public in water resources and services decision-making is presented as more effective than, top-down decision-making [32,44,76], and as a substitute to market-based approaches [23,63].

However, participatory exercises are not separate from society. To achieve their expected outcomes and impacts, and to realize free and meaningful participation, interdependent aspects of public engagement must be recognized, namely:

- the complexities and dynamics of participatory elements need to be well understood;

- specific barriers should be addressed. These includes physical, economic, institutional, attitudinal, and social barriers, as well as other constraints such as gender-stereotypes, self-censorship, power dynamics, and intimidation [19]; and

- participatory processes must be properly designed and implemented. A critical issue is that participatory processes can be captured by elites, and there is always the danger that the established and more powerful voices are disproportionately heard.

Our second aim is to gain insight into what makes a participatory process successful and sustainable [66]. Two types of questions are of relevance: how and to what extent the outcomes and impacts of participation are influenced by (1) contextual factors-e.g., institutional framework, socioeconomic conditions, etc.; and (2) process effectiveness: its inclusivity, access to information, spaces and opportunities for engagement, etc. We analyze these two dimensions as part of the enabling environment for participation.

\section{An Enabling Environment for Meaningful Participation: The Concept and the Practice}

Participation is meant to enable a wider representation in decision-making, and to generate decisions that are better anchored among different groups in society, in particular those that are directly affected by the decisions being made. Unless certain conditions are in place, participation will neither be useful nor meaningful.

Beierle and Konisky [77] identify a number of attributes that may jeopardize the success of participatory efforts. They can be broadly divided into contextual factors and procedural elements. Contextual factors are those that are largely outside the control of agencies or participants. Procedural elements are those over which agencies and participants have considerable control when designing and executing participatory efforts. Building on this distinction, we propose that the contextual factors and procedural elements of participation are interrelated and integrated into what we call the "enabling environment" for free, active, and meaningful participation.

This section elaborates on this enabling environment and responds to the first aim of this paper. We refer to the concept of the enabling environment as the set of attributes that have been highlighted in the literature, mainly from a theoretical perspective, to promote participation. The practice relates to findings and lessons learnt from case studies in which participatory approaches for the design, management, and/or operation of water and sanitation services were adopted and evaluated. They illustrate how participatory processes are implemented in practice, their outcomes, and their impacts. 


\subsection{The Concept: What Are the Attributes of an Enabling Environment?}

The importance given to contextual factors in the analysis of participation is the product of simultaneous developments: the recognition that politics rather than technical processes determine how water is shared between competing claims [78]; the priority given to economic, social or environmental values in policy decisions [79]; and the understanding of participation as an important component of water governance, rather than limited to project-based participation [80,81].

Studies critically assessing participatory approaches have produced recommendations and evidence about contextual factors that enrich the implementation and the evaluation of participation. Theorists contributing to this corpus of water scholarship recommend that project implementers shift their attention away from purely methodological, institutional, and technical problems [82] to consider the "root causes of their dysfunction" [38]. These include wider issues such as the political context, socio-historical legacies, and power dynamics (following the seminal book by [83]) between users and the state $[84,85]$ and, in particular, power differentials among stakeholders with competing interests [85-89]. These scholars suggest moving away from the emphasis on proxies such as meeting attendance sheets to more tangible information about the quality or equity dimensions of participation [90].

Some researchers have investigated aspects of the context that influence the different participatory outcomes [77] and have developed a framework of criteria to evaluate the acceptability of different methods of public participation [35]. The contextual factors identified as crucial for the success of participatory water management include geographical complexity [91]; societal considerations (e.g., demography, culture, history); social and cultural values of local water and sanitation users (e.g., the multiple uses of water resources [59]); and the institutional landscape [92]. The latter includes the type of overarching governance system in place for the country [93], the level at which decisions are made [89], and the existence of power and information asymmetries between duty bearers/decision makers and rights holders/the general public/stakeholder groups [88]. In this vein, Ribot [94] states that establishing a conducive institutional, and legal framework prevents the creation of barriers to participation, particularly in local governance structures in decentralized institutional arrangements. Jiménez and Pérez-Foguet [95] point to the need for coherent bottom-up and top-down planning mechanisms to prevent participatory processes from being ignored when planning major investments. The role of external development agencies is a contextual factor that can critically influence participation. It is argued that their intervention can depoliticize participation by reducing it to a purely technical issue, and support the reproduction of traditional power relationships [88].

With regard to the procedural elements associated with participation, Chilvers [1] identifies seven effectiveness criteria present in participatory processes in the environmental sector: representativeness and inclusivity, fair deliberation, access to resources, transparency and accountability, learning, independence, and efficiency. The "Guide to Public Participation under the Protocol on Water and Health" highlights as core principles of public participation: equity and inclusivity, accountability and transparency, flexibility, effectiveness and speed, and responsiveness [96].

The UN special rapporteur for the human rights to water and sanitation has identified six procedural elements as crucial for achieving free, active, and meaningful participation [19]. First, involving people in setting out the terms of engagement means that people should have influence over the design of the participatory procedures, not only the issues at hand. Second, creating space for participation means that states should actively seek to involve the public in formal and informal ways, and not wait for the public to take initiative. Third, enabling people to access participatory processes is about removing barriers to participation, avoiding "a culture of low expectations and cynicism" (arising from the fact that public officials are not rewarded for facilitating genuine participation, but rather to tick the box, and may lack the necessary facilitation and inter-personal skills), and letting people know how to participate. This would also encompass enabling inclusive processes. This can be achieved by mapping and reaching out to all people concerned, and ensuring that all groups with a stake in the issues are included in the deliberations. Fourth, guaranteeing free and safe 
participation implies that people's participation is voluntary and free from conditions or threats, and that people who engage are protected from reprisals or discrimination. Two measures can support the participation of users and communities who are less able to articulate their demands for services: (1) make participation inclusive — enabling even the most vulnerable to be actively engaged [84] —and (2) provide quality information to show real and existing needs [97]. Effectiveness of participation might also depend on the existence of compensation or incentives for participation [98], and, more broadly, may depend on the participants' perceived benefits from the process. Fifth, ensuring access to information involves sharing complete, timely, and relevant information equally with all stakeholders, and at no cost. States should consider that people learn in different ways: information needs to be presented in different formats, in more than one language if necessary, avoiding technicalities, and employing adequate dissemination tools to engage with specific target groups. Sixth, the commitment of a lead agency to provide reasonable opportunities for influencing decision-making means that there should also be willingness from authorities to engage, listen, and eventually change proposals through the participatory process. States should be accountable, letting people know how their inputs were considered, what decisions were made, and on what grounds.

Recent research adds an additional prerequisite to effective participation of the public: the need to mobilize and raise awareness of both planners and users [96]. For instance, authorities are often ignorant of the benefits of inclusive participation or are reluctant to acknowledge the interest and motivation of the public. On the other hand, citizens may not be aware of public participation opportunities and of their right to partake, or they might not be motivated or willing to participate.

\subsection{The Practice: What Are the Lessons Learnt from the Implementation of Participatory Approaches?}

This section presents examples to illustrate and discuss how an appropriate environment for participation might be enabled or disabled. The analysis makes use of a large number of case studies that exemplify the implementation of participatory approaches in the field of water and sanitation. Each study relates to specific or a combination of procedural elements and contextual factors which affect the participatory impacts and outcomes. Since participatory processes are conducted differently in water and sanitation programs, as well as in rural and urban settings, the examples and discussion are presented separately.

In rural contexts, community management is the most common arrangement for managing drinking-water services delivery [32]. In some countries, half to nearly $90 \%$ of rural water supplies are managed by communities $[99,100]$. The processes aim to strengthen three dimensions: responsibility (in relation to the system and its obligations), authority (i.e., the rights of the community to make decisions about the system), and control (i.e., is the ability to carry out and determine system outcomes) [101]. The assumption is that increased opportunities for users to voice their demand for better services and to participate in decision-making will increase community responsibility and build a public commitment to ensure ongoing services. For this to happen, findings from the case studies highlight the need for sound implementation of measures that support effective participants' involvement, such as shifting the focus of discussions from technical aspects to more management and finance issues, the importance of targeting marginalized groups, and the need to address risks of elite capture. To do this, effective mechanisms should be developed to leverage and respect local forms of knowledge, to ensure adequate information flow, and to raise awareness before and outside of participatory events. The institutional frameworks that underpin these participatory processes needs to be mature, strengthening the role of local governance structures, involving the State, and engaging external support. An inclusive strategy will be dependent on contextual factors, such as the legal representation of all actors, the socio-economic context and profile of participants, and the knowledge of social norms and practices of water. 
Sanitation in rural areas has been encouraged through demonstration infrastructure (latrines), and hygiene promotion campaigns deployed and encouraged to invest in their own sanitation system with or without subsidies. Since then, different intervention models have emerged [102]. Community-wide approaches or 'total sanitation' approaches have been widely adopted to elicit behavioral change and encourage households to invest in the solution they aim for and can afford. However, these approaches to sanitation have a modest impact on latrine coverage and use [103,104]. With regard to participatory issues, different approaches are in place to promote free and safe participation. Some show the importance of integrating and respecting social and cultural norms. Here too, the importance of access to adequate and timely information is highlighted, as well as the need for awareness raising and mobilization for behavior change. In this context, the literature suggests that community participation largely depends on involvement of local leaders, and underlines the crucial role for the state.

In urban, suburban, and peri-urban contexts, the accelerating rate and scale of urban settlement growth raises the demand for water and sanitation services. The public sector is often neither equipped nor capable to respond to these needs [105], particularly in informal settlements [106]. In this context, there is an increasing interest for decentralized options for services delivery. However, populations in suburban and peri-urban areas are typically poor, transient, and non-homogeneous. The complexity of urban water and sanitation systems, and the lack of social cohesion complicate the gathering of public views and involvement in service delivery. Experiences from the field point to the importance of adapting methods of participation to the urban setting, which, in turn, will be influenced by the size of the community and people's attitude towards participation. External support is paramount when size of infrastructure requires significant investments.

These contextual and procedural aspects of participation are summarized in Table 2. Information collected from various cases illustrates the complex nature of participation in practice. The table shows the diversity in approaches adopted to participation in the four fields considered in this study. 
Table 2. Procedural elements and contextual factors that influence participatory outcomes and impacts.

PROCEDURAL ELEMENTS

\section{Rural drinking-water}

Opportunities to influence decision-making: Various studies suggest that water systems are often more sustainable when communities participate in management and finance decisions, and less sustainable when communities engage in technical decisions, and less sustain

Inclusiveness and representativeness: There are specific groups with structural disadvantages when participating [109-111]. In these cases, literature shows that inclusive participatory processes [84] and access to quality information about real needs [97] are two ways to engage less-prepared or marginalized users and communities in timely

articulation of demand for services. Adequate representativeness and leadership of these vulnerable oroups (e.gu indigenous, women, disabled persons, etc.) alse vital to make an outstanding contribution [112,113], e.g., by providing specialist knowledge [114]. In contrast, one factor that undermines participation is the capture of participatory processes and their benefits by bureaucratic and traditional elites $[81,84,115]$

Use of Local Knowledge: Adaptive governance mechanisms [116] and hybrid governance institutions [117] are two examples of management processes intended to integrate indigenous peoples' knowledge.

Access to information: Disseminating information in a clear and understandable manner (e.g., by posters and information leaflets in public places) is essential to facilitate people's engagement in decision-making processes (e.g., budget monitoring) [118]

Mobilization and awareness raising: Awareness raising contributes effectively to increase participation of specific groups, particularly since people lacking access to clean water are those who are less likely to seek support [119].

\section{Rural sanitation}

Free and safe participation: Stakeholders' engagement has been recognized as positive for the acceptance of solutions [130] and for promoting hygiene [56]. From the individual rights perspective, however, various inacceptable measures of pressure have also been reported, e.g., in CLTS approaches $[131,132]$

Inclusiveness: Social and cultural norms may legitimize systematic exclusion of vulnerable groups from decision-making (e.g., failures of the authorities to address risks faced by women when accessing sanitation facilities outside their home [133]). Access to adequate and timely information: Household demand for sanitation can be effectively promoted by ensuring that private benefits of sanitation are clearly understood and perceived by end-users. In this vein, strategic sanitation planning typically combine participatory approaches with sanitation marketing efforts [134].

Awareness raising: Community-led total sanitation relies on a community's capacity for collective action: this approach challenges the dominance of "expert" solutions and subsidies, focusing instead on reflection and behavior change through mobilization [135]
CONTEXTUAL FACTORS

Supportive institutional framework: In decentralized contexts, local governance structures are needed to establish, sustain, and scale up participation [94]. Other studies underline the

necessity for the state to remain actively involved in locally managed services through continued external post-construction monitoring and support [32,71,97,98,100,120-123].

External support: The literature also shows that successful programs managed by communities typically benefit from direct support from external agencies, such as non-governmental organizations, donors or government [97,124].

Legal jurisdiction and recognition: Minority and vulnerable groups (e.g., indigenous people and women) may not be officially recognized in water-related policies and laws [109].

Jurisdiction over water resources and/or water-related services delivery might be contested by these groups.

Socio-economic conditions of participants: Evidence suggest a correlation between the success of participatory approaches and the prevailing socio-economic wealth of a society $[120,125,126]$ and of households [127]; while other scholars show that participants in community-based activities are generally more educated or well-off $[119,125,128]$

Social norms and practices around use of water: One-fit-for-all solution does not work [59]. Instead, participatory approaches need to be built on and adapt to the ways people manage multiple water sources for multiple uses [129].

Supportive institutional framework: The role of the state is crucial, either as a facilitator and coordinator of sanitation governance [136], or as a creator of a conducive environment for "agents of change" to realize their role.

Socio-cultural issues: Presence of village-level leadership, initiative of natural leaders, and social cohesion are factors that promote community participation [103]. Sanitation approaches also need to fit to the standards of comfort users uphold, while respecting cultural beliefs or religious codes [136]

Participation in emergencies: Responding to emergencies poses particular challenges for creating spaces for participation. Many decisions on disaster response are taken beforehand, limiting participation at the planning stage. In relation to menstrual hygiene management during an emergency, for instance, a solution might be to include a standard response for distributing sanitary kits to make sure that immediate needs are met. This response should be monitored subsequently to assess whether cultural preferences and needs of women and girls
monting monitored subsequently to assess whether cultural preferences and needs
are correctly addressed, and then adjust the response accordingly [137]. 
Table 2. Cont

PROCEDURAL ELEMENTS

CONTEXTUAL FACTORS

\section{Urban drinking-water and sanitation}

Opportunities to influence decision-making: The importance of allowing the public to participate in decisions on various aspects of service provision has been highlighted in various studies from both developed and developing contexts (e.g., in deciding on the tariff system and on the extension of services) $[118,138]$.
Understanding the context: The complexities of urban areas are often not conducive to specific sanitation approaches, e.g., Community-Led Total Sanitation [139]

External suppot: The eap Coct External support: The capacity of local organizations in contributing to decisions is directly
jeopardized by the size of infrastructure [76]; the need for institutional support (e.g., technical input, and financing) is therefore bigger in larger water schemes than in smaller rural systems $[98,140]$.

Involvement and coordination of stakeholders: The diversity of socio-institutional actors and interactions across diverse scales encourages approaches based on partnerships over

community-based processes [115]. For example, hybrid partnerships between private water operators with community organizations [141], or the co-production of sanitation services [142] Attitudes towards participation: The influence of community size on their capacity to reach agreements is recognized in the literature [74]. 


\section{Discussion}

Participation is a complex concept and realizing the benefits of participation is challenging. This literature review emphasizes the fundamental importance of the context and participatory methods. In addition, procedural qualities of participation might manifest differently, depending on the context [143]. In place of an exclusive emphasis on one aspect or the other, an enabling environment for meaningful participation needs to consider the implications of both participatory procedures and the contextual settings where they are shaped, and their inter-relations. This requires understanding of the pre-conditions for and expectations of participation, and justifies the need for solid theoretical and empirical grounds in the design and implementation of participatory processes.

The practice of participation takes diverse forms, and the design of participatory processes should consider the context. In rural areas, for instance, the active engagement of users in water services management is the main form of participation. Beyond the conducive institutional and legal framework-including the need for ongoing technical support to small rural service providers-inclusivity and representativeness must remain in focus. To this end, easy and timely access to information is crucial, backed up with community awareness-raising and with recognition and respect for local knowledge.

The participation of urban residents is typically channeled through interactions with consumers about the quality of service (e.g., through user surveys, public meetings or hearings), and consumer protection mechanisms (e.g., complaint mechanisms). In this type of setting, it is crucial to design context-based solutions that enhance the opportunities of users to influence key aspects of service delivery (e.g., tariffs). Service providers must give users adequate instruments to exercise their right to complain. There is also a need for accountable institutions that respond to concrete demands and the needs of citizens. These forms of participation are also relevant in rural contexts, but insufficient institutional capacity often prevents their full implementation [144].

Learning from the key findings presented in the previous discussion, we seek to adopt herein a pragmatic approach. Both the theoretical literature and empirical case studies identify elements and factors associated with meaningful participation. In responding to the second aim of the study, we develop an analytical framework for the concept of participation. The single framework developed here allows us to gain a better understanding and potential operationalization of the enabling environment for meaningful participation. It captures and categorizes the key participatory factors and elements. In doing so, it contributes to the meaningful interpretation of participation and, ultimately, the beneficial implementation of participatory processes.

Conceptually, the Institutional Analysis and Development (IAD) framework developed by E. Ostrom serves as a reference point [145]. In her framework, Ostrom defines the action situation as "the social space where individuals interact, exchange goods and services, solve problems, dominate one another, or fight"; and discusses the variables used to describe the structure of an action situation, including (i) the set of actors or stakeholders, (ii) the specific positions to be filled by participants (e.g., members of a water user association, shopkeepers of water kiosks, etc.), (iii) the set of allowable actions and their linkage to outcomes (e.g., which types of technologies are used in service delivery?), (iv) the potential outcomes that are linked to individual sequences of actions, (v) the level of control over choice (e.g., do participants take the actions on their own initiative?), (vi) the information available to participants (e.g., how much information do participants have about the structure of the action situation?), and (vii) the costs and benefits—which serve as incentives and deterrents-of actions and outcomes [145]. Ostrom also suggests that the rules individuals use to rank their relationships underpin the analysis of an action situation. These rules are the understandings, shared among participants, that refer to enforced prescriptions about what actions are required, permitted or forbidden [145]. She identifies seven types of working rules that affect the structure of an action situation, in accordance with the seven variables cited above. Ostrom recognizes that an action situation is also affected by a diversity of external variables, such as the biophysical conditions, the attributes of the community, and a set of collective-choice rules. 
Drawing on the IAD framework, our proposal (Figure 1) distinguishes between the contextual factors (the "external variables") and the procedural elements that influence the participatory space (the "action situation and the working rules"). The contextual factors define inherent characteristics of the interrelating elements of the context that are relevant for the interpretation of participation. We identify two types of elements within the context. The first, the structural contextual factors, are the factors describing the broader, structural context and external elements that are not amenable to control. These encompass socio-material realities, bringing back issues such as deep-rooted power asymmetries into the analysis of participation. The second type of elements constitutes the "institutional landscape". It comprises elements that can be influenced by management and/or institutional decisions in the mid- to long-term. These include the legal and institutional framework, the role of external support in participatory processes, and the social and informal norms around the use of water and sanitation services, particularly relevant where informal structures such as social capital replace formal structures of management and regulation.

THE ENABLING ENVIRONMENT

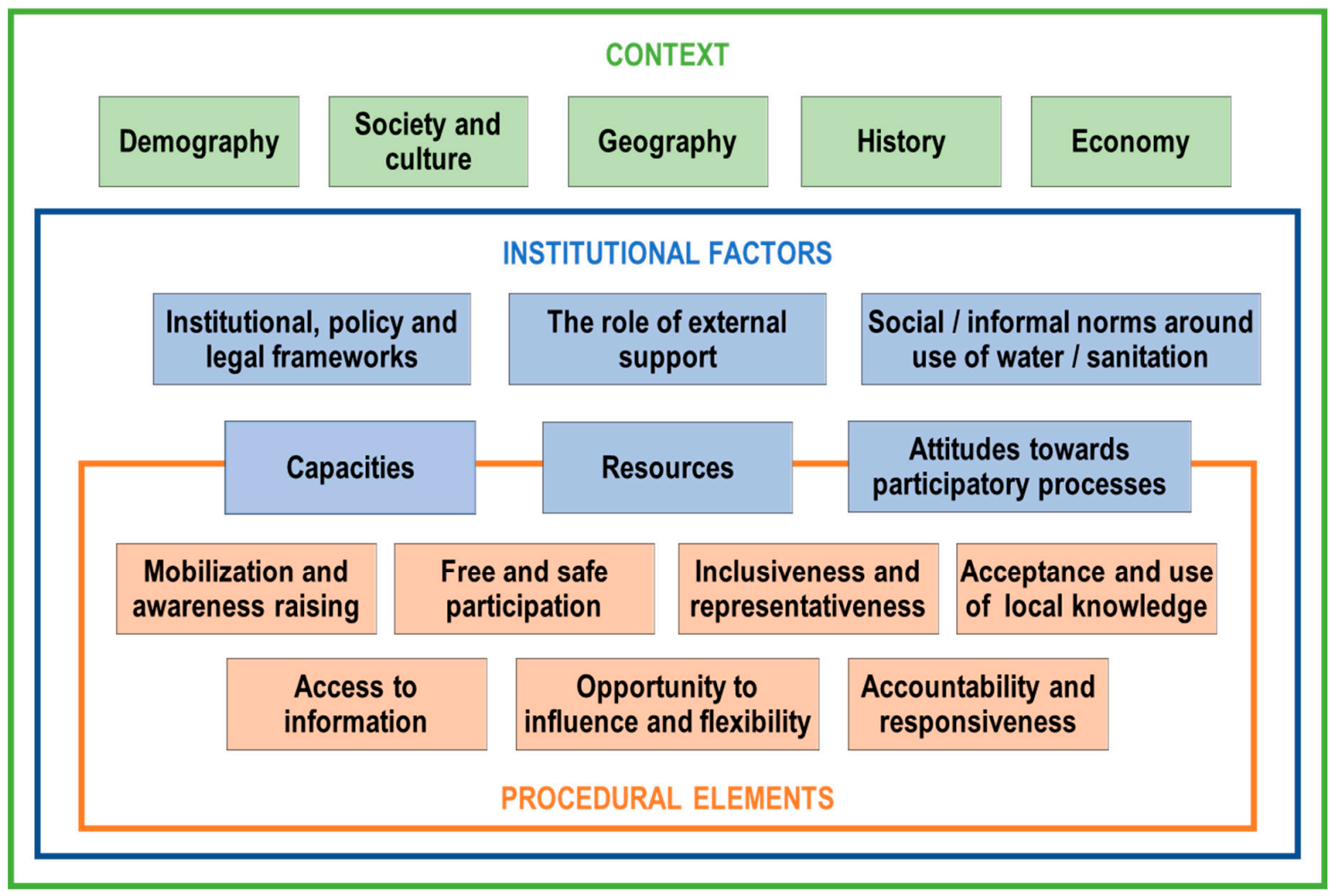

Figure 1. The enabling environment for meaningful participation.

In addressing the procedural elements that should be considered when designing and executing participatory efforts, we follow the typology proposed by the UN special rapporteur [19]. These design principles, rooted in normative theories of deliberative democracy [146], include the procedural standards of free and safe participation, inclusiveness, and representatively, access to information, and opportunity to influence and flexibility (i.e., the possibility to modify and adjust the initial proposal). Mobilization and raising awareness have been also recognized as prerequisites for effective participation by the United Nations Economic Commission for Europe (UNECE) [96], besides accountability and responsiveness. These entail efforts to explain the objectives and the relationship of participation to decision-making, employing democratic mechanisms, publishing results in an understandable and traceable way, and providing complaint or recourse mechanisms $[1,96]$. In addition, identification of, respect for and inclusion of the local knowledge are crucial to guarantee 
that participatory processes are service-oriented and responsive to all social and cultural realities (e.g., indigenous people, poor migrants, or refugees).

Finally, participation is also influenced by the existing capacities for adequate implementation of participatory processes, the amount of available resources that are allocated for this purpose, and the attitudes towards participatory processes. The latter in turn depend on the motivations, incentives, collective and social capital and past experiences of both participants and promoters of the process.

For some scholars, for instance, a problem with community management of drinking-water supplies relates to the issue of "informality and voluntarism", and to the lack of professionalism [147]. Others suggest that communities do not necessarily have the motivation or the ability to engage [148-150]. In addition, voluntarism is hampered by the high turnover of community members, as well as the size [33] and heterogeneity of communities. As noted by Sally et al. [140] smaller schemes are more cohesive and conducive to community participation in service management. As opposed to volunteerism, effectiveness of participation also depends on the existence of compensation or incentives for participation [98], as well as on potential sanctions (negative feedback). Finally, empirical studies [112] suggest that social capital and the sense of ownership simultaneously facilitate community participation and benefit from it. In other words, to support the sustainability of water systems, it makes sense to integrate all three components by mobilizing social capital, while motivating a sense of ownership and establishing community participation norms [112].

Capacities, resources, and attitudes influence and are themselves shaped by the context and the process of participation. To reflect this, they are depicted in an in-between position in Figure 1. The challenge is to accurately understand and support the ways in which the "nodes" that link the context to practices of public engagement can play a positive role in facilitating meaningful participation.

\section{Conclusions}

Experience shows that the benefits of participation do not automatically derive from the existence of a participatory process. In water and sanitation, as formats of participation travel between cultures, times, and places [143], they produce different results. However, when adequately implemented, participatory processes empower participants, and generate greater social awareness about water issues, strengthen the legitimacy of interventions, and, ultimately, improve the delivery and management of water services and their sustainability. Decentering the focus from technicalities of participation to the enabling environment for participation, this article extends the number of elements that must be in place to achieve beneficial participatory outcomes. Beyond the quality of the process, it brings to the fore the importance of crafting initiatives that are politically informed and adapted to the context. The analysis also highlights the importance of mobilizing sufficient financial resources and technical capacities, and the key role played by stakeholders' incentives. The framework presented in this paper seeks to support decision-makers and practitioners: (i) to better understand and embrace the complexity of participation; (ii) to promote a sound implementation of participatory approaches, and ultimately (iii) to ensure that participation delivers on its ambitious promises. Beyond water and sanitation, this framework could be relevant for other areas of environmental management, public services and administration.

Author Contributions: Conceptualization, A.J. and H.L.; literature review, A.J., H.L., J.S., and R.C.; analysis of results and discussion, A.J., H.L., R.G., J.S., R.C., S.M., M.T., and J.B.; writing-original draft, A.J. and R.G.; writing-review and editing, A.J., H.L., R.G., J.S., R.C., S.M., M.T., and J.B. The authors alone are responsible for the views expressed in this article and they do not necessarily represent the views, decisions or policies of the institutions with which they are affiliated.

Funding: Funding for the Stockholm International Water Institute authors was provided by the World Health Organization and the Swedish International Development Cooperation Agency. Funding for the University of North Carolina at Chapel Hill authors was provided by the World Health Organization.

Acknowledgments: This paper has been produced as part of an in-depth study on participation in water and sanitation commissioned by the World Health Organization-led UN-Water Global Analysis and Assessment of 
Sanitation and Drinking-Water (GLAAS) initiative, and conducted together between the Stockholm International Water Institute, the University of North Carolina at Chapel Hill and the GLAAS team.

Conflicts of Interest: The authors declare no conflict of interest.

\section{References}

1. Chilvers, J. Deliberative and Participatory Approaches in Environmental Geography. In A Companion to Environmental Geography; Castree, N., Demeritt, D., Liverman, D., Rhoads, B., Eds.; Wiley-Blackwell: Chichester, UK, 2009; pp. 400-417. ISBN 9781405156226.

2. Enserink, B.; Patel, M.; Kranz, N.; Maestu, J. Cultural Factors as Co-Determinants of Participation in River Basin Management. Ecol. Soc. 2007, 12, art24. [CrossRef]

3. Blair, H. Participation and Accountability at the Periphery: Democratic Local Governance in Six Countries. World Dev. 2000, 28, 21-39. [CrossRef]

4. von Korff, Y.; Daniell, K.A.; Moellenkamp, S.; Bots, P.; Bijlsma, R.M. Implementing Participatory Water Management: Recent Advances in Theory, Practice, and Evaluation. Ecol. Soc. 2012, 17, 30. [CrossRef]

5. Freire, P. Pedagogy of the Oppressed; The Continuum International Publishing Group Ltd.: London, UK, 1970; ISBN 9780826412768.

6. Chambers, R. Rural Development: Putting the Last First; Longman: London, UK, 1983.

7. Cornwall, A. Beneficiary, Consumer, Citizen: Perspectives on Participation for Poverty Reduction; Swedish International Development Corporation Agency: Stockholm, Sweden, 2000.

8. United Nations General Assembly. Declaration on the Right to Development; Resolution A/RES/41/128; United Nations General Assembly: New York, NY, USA, 1986; p. 4.

9. United Nations General Assembly. Report of the Open Working Group of the General Assembly on Sustainable Development Goals; Resolution A/68/970; United Nations General Assembly: New York, NY, USA, 2014; p. 24.

10. International Conference on Water and the Environment (ICWE). The Dublin statement on water and sustainable development. In Proceedings of the International Conference on Water and the Environment, Dublin, Ireland, 31 January 1992.

11. The United Nations Economic Commission for Europe (UNECE). Convention on Access to Information, Public Participation in Decision-making and Access to Justice in Environmental Matters. In Proceedings of the Fourth "Environment for Europe" Ministerial Conference, Aarhus, Denmark, 25 June 1998.

12. The European Parliament and of the Council. EU Water Framework Directive; Directive 2000/60/EC; The European Parliament and of the Council: Brussels, Belgium, 2000.

13. Sustainable Developments. Ministerial Declaration. In Proceedings of the International Conference on Freshwater, Bonn, Germany, 3-7 December 2001.

14. United Nations General Assembly. Transforming our world: The 2030 Agenda for Sustainable Development; Resolution A/RES/70/1; United Nations General Assembly: New York, NY, USA, 2015; p. 35.

15. UN-Water. Means of Implementation: A focus on Sustainable Development Goals 6 and 17; UN-Water: Geneva, Switzerland, 2015.

16. Bartram, J.; Brocklehurst, C.; Bradley, D.; Muller, M.; Evans, B. Policy review of the means of implementation targets and indicators for the sustainable development goal for water and sanitation. npj Clean Water 2018, 1, 3. [CrossRef]

17. Fiorino, D.J. Citizen Participation and Environmental Risk: A Survey of Institutional Mechanisms. Sci. Technol. Hum. Values 1990, 15, 226-243. [CrossRef]

18. Mostert, E. The challenge of public participation. Water Policy 2003, 5, 179-197. [CrossRef]

19. United Nations General Assembly. Report of the Special Rapporteur on the Human Right to Safe Drinking Water and Sanitation: Participation in the Realization of the Human Rights to Water and Sanitation; Resolution A/69/213; United Nations General Assembly: New York, NY, USA, 2014; p. 25.

20. Özerol, G.; Newig, J. Evaluating the success of public participation in water resources management: Five key constituents. Water Policy 2008, 10, 639-655. [CrossRef]

21. Tritter, J.Q.; McCallum, A. The snakes and ladders of user involvement: Moving beyond Arnstein. Health Policy (New York) 2006, 76, 156-168. [CrossRef]

22. Gaventa, J.; Barrett, G. Mapping the Outcomes of Citizen Engagement. World Dev. 2012, 40, $2399-2410$. [CrossRef] 
23. Mansuri, G.; Rao, V. Localizing Development: Does Participation Work? The World Bank: Washington, DC, USA, 2012; ISBN 978-0-8213-8256-1.

24. Green, M. Making Development Agents: Participation as Boundary Object in International Development. J. Dev. Stud. 2010, 46, 1240-1263. [CrossRef]

25. Brett, E.A. The participatory principle in development projects: The costs and benefits of cooperation. Public Adm. Dev. 1996, 16, 5-19. [CrossRef]

26. Carpini, M.X.D.; Cook, F.L.; Jacobs, L.R. Public deliberation, discursive participation, and citizen engagement: A Review of the Empirical Literature. Annu. Rev. Polit. Sci. 2004, 7, 315-344. [CrossRef]

27. Irvin, R.A.; Stansbury, J. Citizen Participation in Decision Making: Is It Worth the Effort? Public Adm. Rev. 2004, 64, 55-65. [CrossRef]

28. Barreteau, O.; Bots, P.W.G.; Daniell, K.A. A Framework for Clarifying "Participation" in Participatory Research to Prevent its Rejection for the Wrong Reasons. Ecol. Soc. 2010, 15, art1. [CrossRef]

29. von Korff, Y.; D'Aquino, P.; Daniell, K.A.; Bijlsma, R. Designing Participation Processes for Water Management and Beyond. Ecol. Soc. 2010, 15, art1. [CrossRef]

30. Coglianese, C. Assessing Consensus: The Promise and Performance of Negotiated Rulemaking. Duke Law J. 1997, 46, 1255-1349. [CrossRef]

31. Mohan, G. Participatory development. In The Arnold Companion to Development Studies; Desai, V., Potter, R., Eds.; Hodder: London, UK, 2001; pp. 49-54. ISBN 978-0-340-76051-2.

32. Harvey, P.A.; Reed, R.A. Community-managed water supplies in Africa: sustainable or dispensable? Community Dev. J. 2007, 42, 365-378. [CrossRef]

33. Doe, S.R.; Khan, M.S. The boundaries and limits of community management: Lessons from the water sector in Ghana. Community Dev. J. 2004, 39, 360-371. [CrossRef]

34. Reed, M.S. Stakeholder participation for environmental management: A literature review. Biol. Conserv. 2008, 141, 2417-2431. [CrossRef]

35. Rowe, G.; Frewer, L.J. Evaluating Public-Participation Exercises: A Research Agenda. Sci. Technol. Hum. Values 2004, 29, 512-556. [CrossRef]

36. Sultana, F. Community and participation in water resources management: gendering and naturing development debates from Bangladesh. Trans. Inst. Br. Geogr. 2009, 34, 346-363. [CrossRef]

37. Wassen, M.J.; Runhaar, H.; Barendregt, A.; Okruszko, T. Evaluating the Role of Participation in Modeling Studies for Environmental Planning. Environ. Plan. B Plan. Des. 2011, 38, 338-358. [CrossRef]

38. Roncoli, C.; Kirshen, P.; Etkin, D.; Sanon, M.; Somé, L.; Dembélé, Y.; Sanfo, B.J.; Zoungrana, J.; Hoogenboom, G. From Management to Negotiation: Technical and Institutional Innovations for Integrated Water Resource Management in the Upper Comoé River Basin, Burkina Faso. Environ. Manage. 2009, 44, 695-711. [CrossRef] [PubMed]

39. Shipley, R.; Utz, S. Making it Count: A Review of the Value and Techniques for Public Consultation. J. Plan. Lit. 2012, 27, 22-42. [CrossRef]

40. De Stefano, L.; De Pedraza Gilsanz, J.; Gil, F.V. A methodology for the evaluation of water policies in European countries. Environ. Manage. 2010, 45, 1363-1377. [CrossRef] [PubMed]

41. Cox, M.; Arnold, G.; Tomás, S.V. A review of design principles for community-based natural resource management. Ecol. Soc. 2010, 15, 38. [CrossRef]

42. Soviana, S. Toward a Sustainable Community-based Enterprise: Organizational Architecture and Performance. Manag. Organ. Stud. 2014, 2, 72-86. [CrossRef]

43. Balazs, C.L.; Lubell, M. Social learning in an environmental justice context: A case study of integrated regional water management. Water Policy 2014, 16, 97-120. [CrossRef]

44. Beierle, T.C. The Quality of Stakeholder-Based Decisions. Risk Anal. 2002, 22, 739-749. [CrossRef]

45. Ricks, J.I. Pockets of participation: Bureaucratic incentives and participatory irrigation management in Thailand. Water Altern. 2015, 8, 193-214.

46. Michaud, W.R. Evaluating the outcomes of collaborative modeling for decision support. J. Am. Water Resour. Assoc. 2012, 49, 693-699. [CrossRef]

47. Blackstock, K.L.; Richards, C. Evaluating stakeholder involvement in river basin planning: A Scottish case study. Water Policy 2007, 9, 493-512. [CrossRef]

48. Lubell, M.; Lippert, L. Integrated regional water management: A study of collaboration or water politics-as-usual in California, USA. Int. Rev. Adm. Sci. 2011, 77, 76-100. [CrossRef] 
49. Burgin, S.; Webb, T.; Rae, D. Stakeholder engagement in water policy: Lessons from peri-urban irrigation. Land Use Policy 2013, 31, 650-659. [CrossRef]

50. Maynard, C.M. Accessing the environment: Delivering ecological and societal benefits through knowledge integration-The case of water management. Appl. Geogr. 2015, 58, 94-104. [CrossRef]

51. Brown, J. Evaluating participatory initiatives in south africa: Not just processes but outcomes too. SAGE Open 2014, 4, 1-16. [CrossRef]

52. Hassenforder, E.; Smajgl, A.; Ward, J. Towards understanding participatory processes: Framework, application and results. J. Environ. Manage. 2015, 157, 84-95. [CrossRef] [PubMed]

53. Burgess, J.; Chilvers, J. Upping the ante: A conceptual framework for designing and evaluating participatory technology assessments. Sci. Public Policy 2006, 33, 713-728. [CrossRef]

54. Das, P. Women's Participation in Community-Level Water Governance in Urban India: The Gap Between Motivation and Ability. World Dev. 2014, 64, 206-218. [CrossRef]

55. Carr, G. Stakeholder and public participation in river basin management-An introduction. Wiley Interdiscip. Rev. Water 2015, 2, 393-405. [CrossRef]

56. Gomez, J.D.; Graham, J.P. Community participation in dry sanitation projects. Water Policy 2004, 6, $249-262$. [CrossRef]

57. Pahl-Wostl, C.; Hare, M. Processes of social learning in integrated resources management. J. Community Appl. Soc. Psychol. 2004, 14, 193-206. [CrossRef]

58. Cornwall, A. Unpacking 'Participation': models, meanings and practices. Community Dev. J. 2008, 43, $269-283$. [CrossRef]

59. Rautanen, S.L.; van Koppen, B.; Wagle, N. Community-driven multiple use water services: Lessons learned by the rural village water resources management project in nepal. Water Altern. 2014, 7, 160-177.

60. Butler, C.; Adamowski, J. Empowering marginalized communities in water resources management: Addressing inequitable practices in Participatory Model Building. J. Environ. Manag. 2015, 153, 153-162. [CrossRef] [PubMed]

61. Holland, J.; Jones, S.; Kardan, A. Understanding participation in development: Towards a framework. Int. Dev. Plan. Rev. 2015, 37, 77-94. [CrossRef]

62. Hickey, S.; Bracking, S. Exploring the Politics of Chronic Poverty: From Representation to a Politics of Justice? World Dev. 2005, 33, 851-865. [CrossRef]

63. Bakker, K. The ambiguity of community: Debating alternatives to private-sector provision of urban water supply. Water Altern. 2008, 1, 236-252.

64. De Stefano, L. Facing the water framework directive challenges: A baseline of stakeholder participation in the European Union. J. Environ. Manag. 2010, 91, 1332-1340. [CrossRef] [PubMed]

65. Bisung, E.; Elliott, S.J. Toward a social capital based framework for understanding the water-health nexus. Soc. Sci. Med. 2014, 108, 194-200. [CrossRef]

66. Carr, G.; Blöschl, G.; Loucks, D.P. Evaluating participation in water resource management: A review. Water Resour. Res. 2012, 48,1-17. [CrossRef]

67. Jones, N.A.; Perez, P.; Measham, T.G.; Kelly, G.J.; d'Aquino, P.; Daniell, K.A.; Dray, A.; Ferrand, N. Evaluating Participatory Modeling: Developing a Framework for Cross-Case Analysis. Environ. Manage. 2009, 44, 1180. [CrossRef] [PubMed]

68. Masschelein, J.; Quaghebeur, K. Participation Making a Difference? Critical Analysis of the Participatory Claims of Change, Reversal, and Empowerment. Interchange 2006, 37, 309-331. [CrossRef]

69. Benson, D.; Jordan, A.; Huitema, D. Involving the Public in Catchment Management: An Analysis of the Scope for Learning Lessons from Abroad. Environ. Policy Gov. 2012, 22, 42-54. [CrossRef]

70. Ramsey, K. A Call for Agonism: GIS and the Politics of Collaboration. Environ. Plan. A Econ. Sp. 2008, 40, 2346-2363. [CrossRef]

71. Fielmua, N. The Role of the Community Management Model towards Improved and Sustainable Access to Potable Water in Ghana (A Case of Nadowli District). J. Sustain. Dev. 2011, 4, 174-184. [CrossRef]

72. Marks, S.J.; Davis, J. Does User Participation Lead to Sense of Ownership for Rural Water Systems? Evidence from Kenya. World Dev. 2012, 40, 1569-1576. [CrossRef]

73. Newig, J.; Fritsch, O. Environmental governance: participatory, multi-level-and effective? Environ. Policy Gov. 2009, 19, 197-214. [CrossRef] 
74. Madrigal-Ballestero, R.; Alpízar, F.; Schlüter, A. Public perceptions of the performance of community-based drinking water organizations in Costa Rica. Water Resour. Rural Dev. 2013, 1-2, 43-56. [CrossRef]

75. Chowns, E. Is Community Management an Efficient and Effective Model of Public Service Delivery? Lessons from the Rural Water Supply Sector in Malawi. Public Adm. Dev. 2015, 35, 263-276. [CrossRef]

76. Madrigal, R.; Alpízar, F.; Schlüter, A. Determinants of Performance of Community-Based Drinking Water Organizations. World Dev. 2011, 39, 1663-1675. [CrossRef]

77. Beierle, T.C.; Konisky, D.M. Values, conflict, and trust in participatory environmental planning. J. Policy Anal. Manag. 2000, 19, 587-602. [CrossRef]

78. Bourblanc, M. Social Participation in Water Governance and Management: Critical and Global Perspectives. Int. J. Water Resour. Dev. 2010, 26, 709-713. [CrossRef]

79. Butterworth, J.; Warner, J.; Moriarty, P.; Smits, S.; Batchelor, C. Finding practical approaches to integrated water resources management. Water Altern. 2010, 3, 68-81.

80. Lockwood, H.; Smits, S. Supporting Rural Water Supply; Practical Action Publishing: Rugby, UK, 2011; ISBN 9781853397295.

81. Jones, S. Participation as citizenship or payment? A case study of rural drinking water governance in Mali. Water Altern. 2011, 4, 54-71.

82. Bergh, S.I. Democratic decentralisation and local participation: A review of recent research. Dev. Pract. 2004, 14, 780-790. [CrossRef]

83. Cooke, B.; Kothari, U. Participation: The New Tyranny? Cooke, B., Kothari, U., Eds.; Zed Books: London, UK, 2001; ISBN 978-1856497947.

84. van Koppen, B.; Cossio-Rojas, V.; Skielboe, T. Project politics, priorities and participation in rural water schemes. Water Altern. 2012, 5, 1-15.

85. O'Reilly, K.; Dhanju, R. Hybrid drinking water governance: Community participation and ongoing neoliberal reforms in rural Rajasthan, India. Geoforum 2012, 43, 623-633. [CrossRef]

86. Brown, J.R. “Whisky's fer Drinkin"; Water's fer Fightin'!" Is It? Resolving a Collective Action Dilemma in New Mexico.". Nat. Resorces J. 2003, 43, 185-221.

87. Wagenet, L.P.; Pfeffer, M.J. Organizing Citizen Engagement for Democratic Environmental Planning. Soc. Nat. Resour. 2007, 20, 801-813. [CrossRef]

88. Williams, G. Evaluating Participatory Development: Tyranny, Power and (Re) Politicisation. Third World $Q$. 2004, 25, 557-578. [CrossRef]

89. Mohan, G.; Stokke, K. Participatory Development and Empowerment: The Dangers of Localism. Third World Q. 2000, 21, 247-268. [CrossRef]

90. Morinville, C.; Harris, L.M. Participation, politics, and panaceas: exploring the possibilities and limits of participatory urban water governance in Accra, Ghana. Ecol. Soc. 2014, 19, art36. [CrossRef]

91. Harding, J.S.; Benfield, E.F.; Bolstad, P.V.; Helfman, G.S.; Jones, E.B.D. Stream biodiversity: The ghost of land use past. Proc. Natl. Acad. Sci. 1998, 95, 14843-14847. [CrossRef] [PubMed]

92. Soviana, S.; Kühl, R. Towards a sustainable community-based management: an assessment of community participation level. Int. J. Sustain. Soc. 2010, 2, 341-354. [CrossRef]

93. de Boer, C.; Vinke-de Kruijf, J.; Özerol, G.; Bressers, H. Collaborative Water Resource Management: What makes up a supportive governance system? Environ. Policy Gov. 2016, 26, 229-241. [CrossRef]

94. Ribot, J.C. Waiting for Democracy: The Politics of Choice in Natural Resource Decentralization; Schultz, M., Yaghmour, E., Eds.; World Resources Institute: Washington, DC, USA, 2004; ISBN 1569735646.

95. Jiménez, A.; Pérez Foguet, A. Implementing pro-poor policies in a decentralized context: The case of the Rural Water Supply and Sanitation Program in Tanzania. Sustain. Sci. 2011, 6, 37-49. [CrossRef]

96. United Nations Economic Commission for Europe (UNECE). Guide to Public Participation under the Protocol on Water and Health; UNECE: Geneva, Switzerland, 2013.

97. Jiménez, A.; Pérez Foguet, A. Challenges for Water Governance in Rural Water Supply: Lessons Learned from Tanzania. Int. J. Water Resour. Dev. 2010, 26, 235-248. [CrossRef]

98. Kleemeier, E. The Impact of Participation on Sustainability: An Analysis of the Malawi Rural Piped Scheme Program. World Dev. 2000, 28, 929-944. [CrossRef]

99. Klug, T.; Cronk, R.; Shields, K.F.; Bartram, J. A categorization of water system breakdowns: Evidence from Liberia, Nigeria, Tanzania, and Uganda. Sci. Total Environ. 2018, 619-620, 1126-1132. [CrossRef] 
100. Cronk, R.; Bartram, J. Factors Influencing Water System Functionality in Nigeria and Tanzania: A Regression and Bayesian Network Analysis. Environ. Sci. Technol. 2017, 51, 11336-11345. [CrossRef] [PubMed]

101. McCommon, C.; Warner, D.; Yohalem, D. Community Management of Rural Water Supply and Sanitation Services; UNDP and The World Bank-Water and Sanitation Program: Washington, DC, USA, 1990.

102. Jiménez, A.; Mtango, F.F.; Cairncross, S. What role for local government in sanitation promotion? Lessons from Tanzania. Water Policy 2014, 16, 1104-1120. [CrossRef]

103. Venkataramanan, V.; Crocker, J.; Karon, A.; Bartram, J. Community-Led Total Sanitation: A Mixed-Methods Systematic Review of Evidence and Its Quality. Environ. Health Perspect. 2018, 126, 26001. [CrossRef] [PubMed]

104. Crocker, J.; Abodoo, E.; Asamani, D.; Domapielle, W.; Gyapong, B.; Bartram, J. Impact Evaluation of Training Natural Leaders during a Community-Led Total Sanitation Intervention: A Cluster-Randomized Field Trial in Ghana. Environ. Sci. Technol. 2016, 50, 8867-8875. [CrossRef] [PubMed]

105. Ahmed, S.A.; Ali, S.M. People as partners: Facilitating people's participation in public-private partnerships for solid waste management. Habitat Int. 2006, 30, 781-796. [CrossRef]

106. Otsuki, K. Infrastructure in informal settlements: Co-production of public services for inclusive governance. Local Environ. 2016, 21, 1557-1572. [CrossRef]

107. Marks, S.J.; Komives, K.; Davis, J. Community Participation and Water Supply Sustainability: Evidence from Handpump Projects in Rural Ghana. J. Plan. Educ. Res. 2014, 34, 276-286. [CrossRef]

108. Musembi, S. Scaling up CLTS in Kenya: Opportunities, challenges and lessons. In Tales of Shit: Community-Led Total Sanitation in Africa; Participatory Learning and Action (PLA): London, UK, 2010; Volume 61.

109. Jiménez, A.; Cavill, S.; Cairncross, S. The neglect of hygiene promotion in developing countries, as shown by the Global Analysis and Assessment of Sanitation and Drinking-Water survey. J. Water Sanit. Hyg. Dev. 2014, 4, 240-247. [CrossRef]

110. Poirier, R.; Schartmueller, D. Indigenous water rights in Australia. Soc. Sci. J. 2012, 49, 317-324. [CrossRef]

111. Ruru, J. The Legal Voice of Māori in Freshwater Governance: A Literature Review; Manaaki Whenua-Landcare Research: Lincoln, New Zealand, 2009.

112. Kelly, E.; Lee, K.; Shields, K.F.; Cronk, R.; Behnke, N.; Klug, T.; Bartram, J. The role of social capital and sense of ownership in rural community-managed water systems: Qualitative evidence from Ghana, Kenya, and Zambia. J. Rural Stud. 2017, 56, 156-166. [CrossRef]

113. Galaa, S.Z.; Bukari, F.I.M. Water tariff conflict resolution through indigenous participation in tri-water sector partnerships: Dalun cluster communities in northern Ghana. Dev. Pract. 2014, 24, 722-734. [CrossRef]

114. Parry-Jones, S.; Reed, R.; Skinner, B.H. Sustainable Handpump Projects in Africa: A Literature Review; Water, Engineering and Development Centre, Loughborough University: Loughborough, UK, 2001.

115. Adams, E.A.; Zulu, L.C. Participants or customers in water governance? Community-public partnerships for peri-urban water supply. Geoforum 2015, 65, 112-124. [CrossRef]

116. Bark, R.H.; Barber, M.; Jackson, S.; Maclean, K.; Pollino, C.; Moggridge, B. Operationalising the ecosystem services approach in water planning: a case study of indigenous cultural values from the Murray-Darling Basin, Australia. Int. J. Biodivers. Sci. Ecosyst. Serv. Manag. 2015, 11, 239-249. [CrossRef]

117. Memon, P.A.; Kirk, N. Role of indigenous Māori people in collaborative water governance in Aotearoa/New Zealand. J. Environ. Plan. Manag. 2012, 55, 941-959. [CrossRef]

118. de Albuquerque, C.; Roaf, V. On the Right Track: Good Practices in Realising the Rights to Water and Sanitation; UN Special Rapporteur on the Human Right to Safe Drinking Water and Sanitation: Lisbon, Portugal, 2012; ISBN 978-989-8360-09-0.

119. Holvoet, N.; Dewachter, S.; Molenaers, N. Look Who's Talking. Explaining Water-Related Information Sharing and Demand for Action Among Ugandan Villagers. Environ. Manag. 2016, 58, 780-796. [CrossRef] [PubMed]

120. Hutchings, P.; Chan, M.Y.; Cuadrado, L.; Ezbakhe, F.; Mesa, B.; Tamekawa, C.; Franceys, R. A systematic review of success factors in the community management of rural water supplies over the past 30 years. Water Policy 2015, 17, 963-983. [CrossRef]

121. Rout, S. Institutional variations in practice of demand responsive approach: Evidence from rural water supply in India. Water Policy 2014, 16, 650-668. [CrossRef]

122. Subramanian, A.; Jagannathan, N.V.; Meinzen-Dick, R. (Eds.) User Organizations for Sustainable Water Services; World Bank Technical Papers; The World Bank: Washington, DC, USA, 1997; ISBN 978-0-8213-3855-1. 
123. Goldin, J.A. The participatory paradigm: Anathema, praise and confusion. In Contemporary Water Governance in the Global South-Scarcity, Marketization and Participation; Harris, L.M., Goldin, J.A., Sneddon, C., Eds.; Routledge: Abingdon-on-Thames, UK, 2013; p. 264.

124. Hutchings, P.; Franceys, R.; Mekala, S.; Smits, S.; James, A.J. Revisiting the history, concepts and typologies of community management for rural drinking water supply in India. Int. J. Water Resour. Dev. 2017, 33, 152-169. [CrossRef]

125. Prokopy, L.S. Determinants and Benefits of Household Level Participation in Rural Drinking Water Projects in India. J. Dev. Stud. 2009, 45, 471-495. [CrossRef]

126. Prokopy, L.S.; Thorsten, R. The Role of Wealth, Income, and Social Capital in Determining a Household's Choice to Participate in Rural Water-Supply Projects in Peru. Environ. Plan. C Gov. Policy 2008, 26, 1162-1176. [CrossRef]

127. Nisha, K.R. Household participation in community-based rural water supply systems: Experience from Kerala, India. Water Policy 2013, 15, 515-534. [CrossRef]

128. Tigabu, A.D.; Nicholson, C.F.; Collick, A.S.; Steenhuis, T.S. Determinants of household participation in the management of rural water supply systems: A case from Ethiopia. Water Policy 2013, 15, 985-1000. [CrossRef]

129. Smits, S.; van Koppen, B.; Moriarty, P.; Butterworth, J. Multiple-use services as an alternative to rural water supply services: A characterisation of the approach. Water Altern. 2010, 3, 102-121.

130. Roma, E.; Jeffrey, P. Evaluation of community participation in the implementation of community-based sanitation systems: A case study from Indonesia. Water Sci. Technol. 2010, 62, 1028-1036. [CrossRef] [PubMed]

131. Brewis, A.; Wutich, A.; du Bray, M.V.; Maupin, J.; Schuster, R.C.; Gervais, M.M. Community hygiene norm violators are consistently stigmatized: Evidence from four global sites and implications for sanitation interventions. Soc. Sci. Med. 2019, 220, 12-21. [CrossRef] [PubMed]

132. Bartram, J.; Charles, K.; Evans, B.; O'Hanlon, L.; Pedley, S. Commentary on community-led total sanitation and human rights: Should the right to community-wide health be won at the cost of individual rights? J. Water Health 2012, 10, 499-503. [CrossRef] [PubMed]

133. Lennon, S. Fear and Anger: Perceptions of Risks Related to Sexual Violence against Women Linked to Water and Sanitation in Delhi, India; SHARE (Sanitation and Hygiene Applied Research for Equity) and WaterAid: London, UK, 2011.

134. Cairncross, S. The Case for Marketing Sanitation; The World Bank: Nairobi, Kenya, 2004.

135. Kar, K.; Chambers, R. Handbook on Community-Led Total Sanitation; Plan UK and Institute of Development Studies (IDS): Brighton, UK, 2008.

136. van Vliet, B.J.M.; Spaargaren, G.; Oosterveer, P. Sanitation under challenge: Contributions from the social sciences. Water Policy 2011, 13, 797-809. [CrossRef]

137. Sommer, M. Menstrual hygiene management in humanitarian emergencies: Gaps and recommendations. Waterlines 2012, 31, 83-104. [CrossRef]

138. Zhong, L.-J.; Mol, A.P.J. Participatory environmental governance in China: Public hearings on urban water tariff setting. J. Environ. Manag. 2008, 88, 899-913. [CrossRef]

139. Das, P. The urban sanitation conundrum: What can community-managed programmes in India unravel? Environ. Urban. 2015, 27, 505-524. [CrossRef]

140. Sally, Z.; Gaskin, S.J.; Folifac, F.; Kometa, S.S. The effect of urbanization on community-managed water supply: case study of Buea, Cameroon. Community Dev. J. 2014, 49, 524-540. [CrossRef]

141. Akbar, H.M.D.; Minnery, J.R.; van Horen, B.; Smith, P. Community water supply for the urban poor in developing countries: The case of Dhaka, Bangladesh. Habitat Int. 2007, 31, 24-35. [CrossRef]

142. Burra, S.; Patel, S.; Kerr, T. Community-designed, built and managed toilet blocks in Indian cities. Environ. Urban. 2003, 15, 11-32. [CrossRef]

143. Soneryd, L. Technologies of participation and the making of technologized futures. In Remaking Participation: Science, Environment and Emergent Publics; Chilvers, J., Kearnes, M., Eds.; Routledge: New York, NY, USA, 2016; pp. 144-161, ISBN 9781135084707.

144. Jiménez, A.; Livsey, J.; Åhlén, I.; Scharp, C.; Takane, M. Global assessment of accountability in water and sanitation services using GLAAS data. Water Altern. 2018, 11, 238-259. 
145. Ostrom, E. Background on the Institutional Analysis and Development Framework. Policy Stud. J. 2011, 39, 7-27. [CrossRef]

146. Dryzek, J.S. Deliberative Democracy and Beyond; Oxford University Press: Oxford, UK, 2002; ISBN 9780199250431.

147. Moriarty, P.; Smits, S.; Butterworth, J.; Franceys, R. Trends in rural water supply: Towards a service delivery approach. Water Altern. 2013, 6, 329-349.

148. Salami, A.O.; Stampini, M.; Kamara, A.B.; Sullivan, C.A.; Namara, R. Development aid and access to water and sanitation in Sub-Saharan Africa. Water Int. 2014, 39, 294-314. [CrossRef]

149. Das, P.; Takahashi, L. Non-participation of low-income households in community-managed water supply projects in India. Int. Dev. Plan. Rev. 2014, 36, 265-291. [CrossRef]

150. Golooba-Mutebi, F. In search of the right formula: public, private and community-driven provision of safe water in Rwanda and Uganda. Public Adm. Dev. 2012, 32, 430-443. [CrossRef]

(C) 2019 by the authors. Licensee MDPI, Basel, Switzerland. This article is an open access article distributed under the terms and conditions of the Creative Commons Attribution (CC BY) license (http:/ / creativecommons.org/licenses/by/4.0/). 